\title{
Chennai Floods (2015) and Possible Solutions from Developed Countries
}

\author{
Saravanan $\mathbf{J}^{1}$, Naveen Chander $\mathbf{K}^{2}$ \\ ${ }^{1}$ Assistant Professor, Civil Engineering, Renganayagi Varatharaj College of Engineering, Sivakasi, TamilNadu, India \\ ${ }^{2}$ Post Graduate in Environmental Engineering, BIM Modeler, SYConE CPMC Pvt.Ltd. Bangalore, India
}

\begin{abstract}
A number of major cities and towns in India reported a series of devastating urban floods in the recent decade. Mumbai flood 2005 followed by other major cities of South Asia like Dhaka, Islamabad, Rawalpindi also suffered with urban flooding. Chennai, one of the fast growing metros is likely affected by the lack of drainage mainly due to uncontrolled developments of concrete spaces, encroachment of major drainage channels, shrinking of marshlands, etc.,. Though Urbanization, the vital factor of response for the flood risks is coupled with the climatic variability and ecological imbalances. In this paper, we have discussed about the caustic factors of Chennai Floods during Nov-Dec 2015. And we have discussed in detail about the Urban Flood Management Strategies which have been implemented in various developed countries such as UK, Malaysia, Australia and Japan.
\end{abstract}

Keywords: Chennai Floods, Urban Flood Management, Thames Barrier, SMART tunnel, Retarding Basin

\section{Introduction}

Chennai is located at $13.04^{\circ} \mathrm{N} 80.17^{\circ} \mathrm{E}$ on the southeast coast of India and in the northeast corner of TamilNadu. It is located on a flat coastal plain known as the Eastern Coastal Plains. The city has an average elevation of 6 meters $(20 \mathrm{ft})$. Its highest point being $60 \mathrm{~m}(200 \mathrm{ft})$.

\subsection{Geology of Chennai}

The geology of Chennai comprises mostly clay, shale and sandstone. The city is classified into three regions based on geology as:

- Sandy Areas

- Clayey Areas

- Hard-rock Areas

Sandy areas are found along the banks and coasts. Clayey regions cover most of the city. Hard rock areas are Guindy, Velachery, Adambakkam and a part of Saidapet. In sandy areas such as Thiruvanmiyur, Adyar, Kottivakkam, Santhome, George Town, Tondiarpet and the rest of coastal Chennai, rainwater run-off percolates very quickly. In clayey and hard rock areas, rainwater percolates slowly, but it is held by the soil for a longer time. The city's clayey areas include T.Nagar, West Mambalam, Anna Nagar, Perumbalur and Virugambakkam.

\section{North-East Monsoon 2015}

During North-East monsoon, 2015, Chennai and other parts of rain-ravaged TamilNadu were left marooned and flooded with signs of devastation caused by the nature's fury. Over 270 lives have lost till now in the flash-floods. Normal life came to a grinding halt as schools, colleges, offices, IT forms and shops had to face complete shutdown.

\subsection{Record Breaking Rain fall}

The total rainfall in Chennai was $119.73 \mathrm{~cm}$ till November 30 , midnight (2015) has broken the 1918 record of $108.8 \mathrm{~cm}$ which had stood as the highest record.

Chennai has so far received $539 \mathrm{~mm}$ of rain in December as against the monthly average of $191 \mathrm{~mm}$. Chennai rain in December was almost 3 times more than the normal rainfall in December.

It has also broken the record of last ten years when the capital city received $421 \mathrm{~mm}$ of rain in 2005. (Source: Skymet Meteorology, India Division)

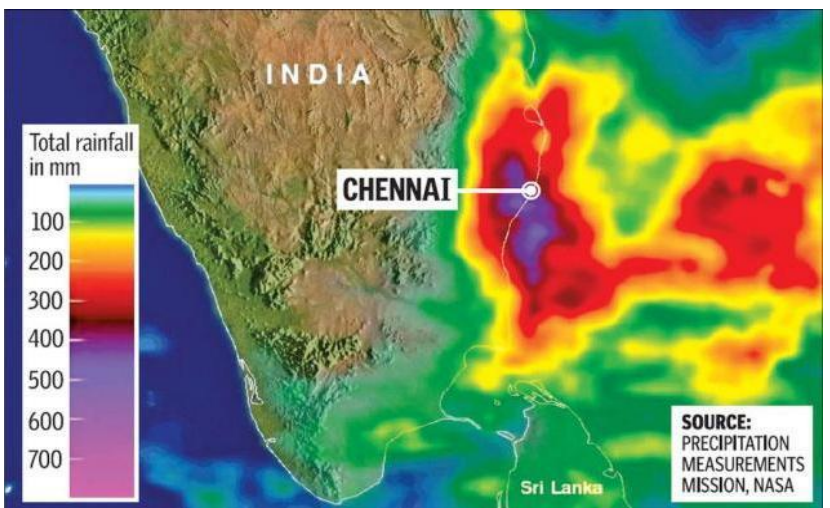

Figure 1: NASA Map showing rain intensity in Chennai between Nov 28 and Dec 4, 2015

(Source: PMM, NASA) 


\section{International Journal of Science and Research (IJSR) \\ ISSN (Online): 2319-7064}

Index Copernicus Value (2013): 6.14 | Impact Factor (2014): 5.611

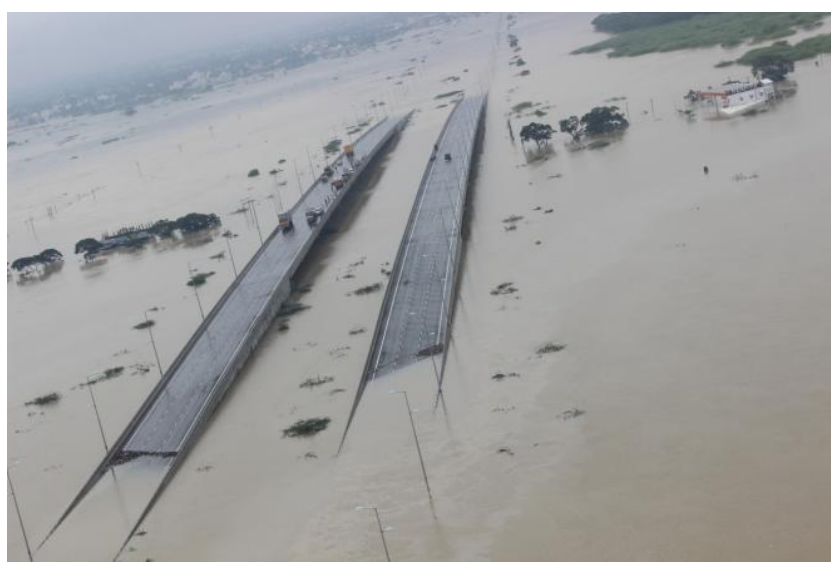

Figure 2: Submerged Bridges due to Flood (Source: Indian Air Force)

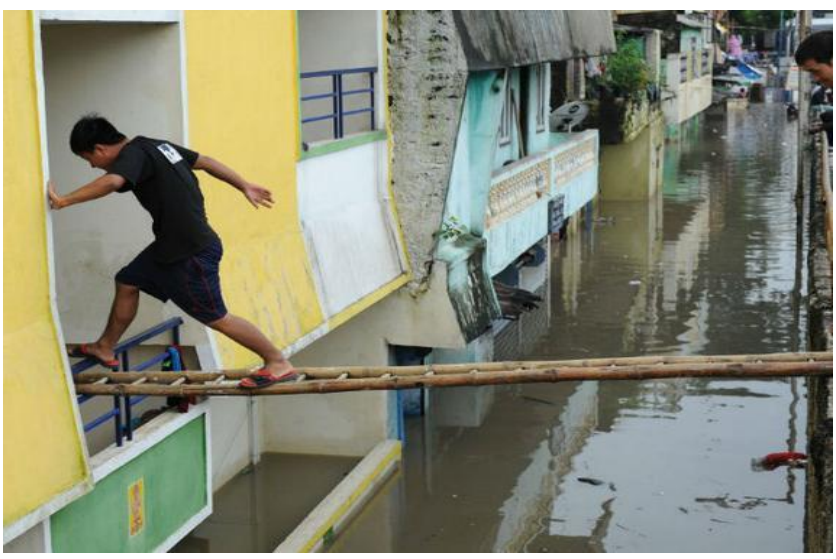

Figure 3: Flooded Street in Mudichur, West Tambaram (Source: The Hindu)

\section{Caustic Factors for Chennai Floods}

Tamil Nadu Chief Minister J Jayalalithaa's response to the floods in Tamil Nadu is a kind frightening. A report in NDTV quotes her saying as, tosses are unavoidable when there's very heavy rain. Swift rescue and relief alone are indicators of a good government." These words are intended to normalize a human-made disaster, and gloss over the pathology of urban development under successive administrations. An analysis shows that in just four decades, urbanization in the Chennai city increased by almost 20 times. The caustic factors for Chennai flood damages are summarized as below.

\subsection{Natural Geography}

Much of the flood damages are the consequence of Chennai's geography. The city is spread across a low-lying area and is flat like a pancake. The average elevation of the city is only about 6.7 meters above mean sea level, with many neighborhoods actually at sea level, which makes drainage a challenge even under normal circumstances.

\subsection{Sewage Infrastructure}

Chennai's first sewage plan was conceived in the 1860s and a proper system was installed in 1891. Improved and expanded since, including a zonal reorganization in the 1960s, it hasn't been able to keep up. There simply aren't enough sewage lines and pumps to deal with Chennai's population and flat terrain.

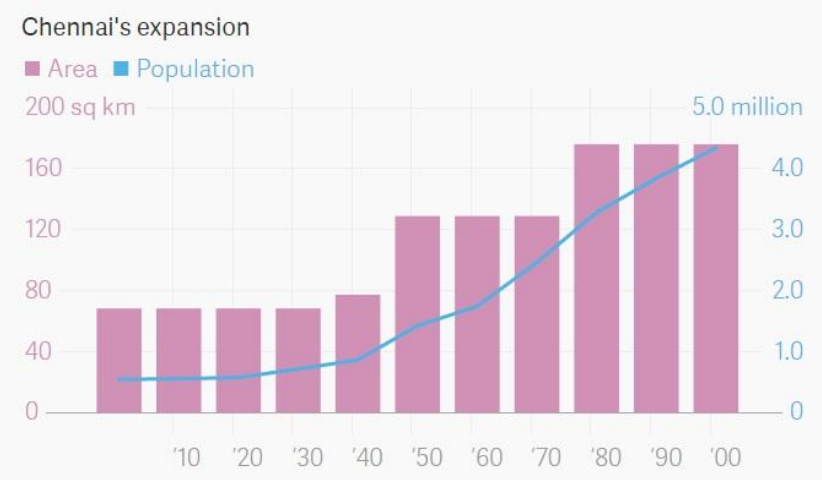

Figure 4: Chennai’s Population Scenario (Source: India Census)

The sewage system in Chennai was originally designed for a population of 0.65 million at 114 litres per capita per day of water supply; it was further modified during 1989-1991, but is now much below the required capacity," a 2011 study by members of the National Institute of Disaster Management (NIDM) noted. It has been told that The city has only 855 $\mathrm{km}$ of storm drains against 2,847 $\mathrm{km}$ of urban roads." (with reference to reports of NIDM)

\subsection{Ponds and Pavements}

It hasn't helped that the city's network of about 650 water bodies - including big lakes, ponds and storage tanks - has been destroyed. The current number stands at around 27, according to the NIDM study. Even those water bodies that have managed to survive are much smaller than before.

For instance, the total area of 19 major lakes in the city has nearly halved from 1,130 hectares to about 645 hectares. This has meant that the overall capacity of water bodies in the city to contain excess rain water has reduced.

Chennai's land use pattern has also altered, with some areas where -almost $99 \%$ of the green cover has been replaced by non-vegetative development," the NIDM study reported. - As a result, the water-holding capacity of the city's surface has gone down drastically," the study added. Together with an increase in impermeable surfaces such as paved roads and other construction, the peak flow-or, the maximum instantaneous discharge of water-in some areas has increased by $89 \%$ between 1997 and 2001 .

\subsection{Devastating of Pallikaranai (Flood Sink of the City) Marsh Land}

The city has large marsh in the south (about $20 \mathrm{~km}$ south of the city center), smaller satellite wetlands around it and large tract of pasture land. The southern marshland called Pallikaranai marshland is known as the flood sink area of the city as it drained about 250 sq. $\mathrm{km}$ of the city in the eighties.

The marshland that was around 5,000 hectares (ha) during independence got reduced to almost 600 ha around 2010-11. The only reason for all this was rapid urbanization.

\section{Volume 4 Issue 12, December 2015}




\section{International Journal of Science and Research (IJSR) \\ ISSN (Online): 2319-7064}

Index Copernicus Value (2013): 6.14 | Impact Factor (2014): 5.611

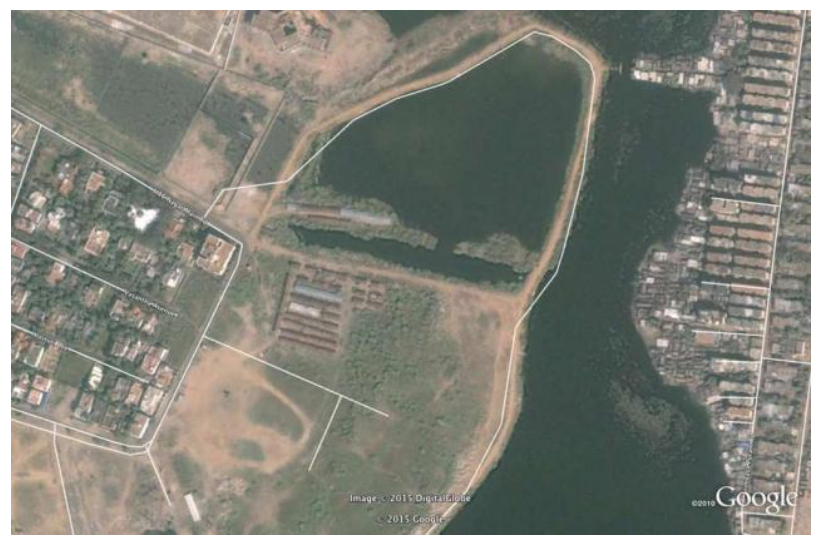

Figure 5A: M.R.C Nagar, Chennai in 2001

(Source: Google Maps)

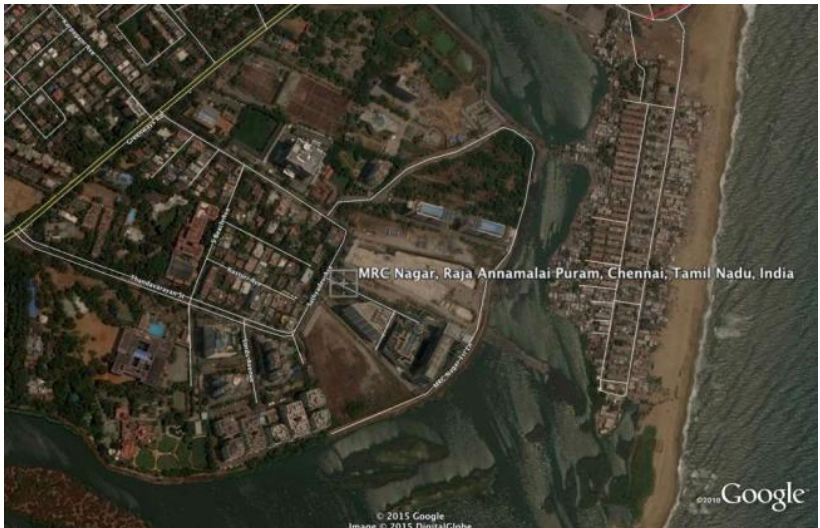

Figure 5B: M.R.C Nagar, Chennai in 2015 (Source: Google Maps)

During this time (2010-11) along with the marshland, all other wetlands of Chennai became sites of waste disposal, housing, commercial and industrial purposes. As the city expanded in the south, Pallikaranai marsh became fragmented. As any other city, the state of Tamil Nadu only valued the land and not the water body which came to be treated as wasteland.

The city found this marsh most suitable place for urban development. The area was allotted to the Mass Rapid Transport System of the Ministry of Railways, the National Institute of Ocean Technology, the Chennai Corporation, and the Centre for Wind Energy Technology.

In 2002, a survey by the Tamil Nadu Pollution Control Board showed that that the marsh lost around 90 per cent of its original extent. This is also the year when the city observed a big flood event. The most affected areas were the adjoining areas around the marsh.

The most prominent Perungudi dump yard that spans over 75.22 ha is located on the north-eastern part of the marsh. The area of the dump yard has doubled over the last decade with an increase from 32 ha in 2002-03 to about 75 ha in 2013, according to Tamil Nadu State Land Use Research Board. It shows that around 273.50 ha was allotted to different institutions by 2010 . Over and above this, there are other allotments that made the total allotment area of 474 ha area already allotted or occupied. (Sakthivel et.al)
Table 1: Change in Pallikaranai Marsh between 2003 and 2005

\begin{tabular}{|c|c|c|}
\hline Segment & 2003 & 2005 \\
\hline Garbage dump & $50.25 \mathrm{ha}$ & $57.24 \mathrm{ha}$ \\
\hline Area impacted by garbage dumping/sewage & $58.75 \mathrm{ha}$ & $132.25 \mathrm{ha}$ \\
\hline Northern Segment & $227 \mathrm{ha}$ & $150.56 \mathrm{ha}$ \\
\hline Southern segment & $284 \mathrm{ha}$ & $279.65 \mathrm{ha}$ \\
\hline
\end{tabular}

(Source: Vencatesan, J, 2007, Protecting wetlands, Current Science)

Table 2: Legal Buildings on the Pallikaranai Marsh land

\begin{tabular}{|l|c|}
\hline \multicolumn{1}{|c|}{ Building } & $\begin{array}{c}\text { Area } \\
\text { Occupied } \\
(\text { ha })\end{array}$ \\
\hline Metropolitan Rapid Transport System (MRTS) & 92.405 \\
\hline Film Employees Federation of South India (FEFSI) & 34.410 \\
\hline Ashram Latha Rajnikanth Trust & 5 \\
\hline Tamil Nadu Agricultural Marketing Board & 12.150 \\
\hline Dr. Ambedkar Law University & 8.100 \\
\hline Judicial Academy & 6.070 \\
\hline MMRD Road 200' width & 13.600 \\
\hline IIT, Chennai & 17.810 \\
\hline National Institute of Ocean Technology (NIOT) & 20.250 \\
\hline Government Free Pattas & 2 \\
\hline Land allotted for Ex-servicemen & 61.675 \\
\hline Total & $\mathbf{2 7 3 . 6 0}$ \\
\hline
\end{tabular}

(Source: Department of Geography, University of Madras)

By 2014, about Rs.394 crores of that amount had been spent by the Tamil Nadu government but, as the Comptroller and Auditor General noted, it hadn't done much to protect Chennai from flooding. Evidently, good money has been spent down the drain.

\section{Urban Flood Protection Measures}

\subsection{Thames Barrier (London) from United Kingdom}

The Thames Barrier is a unique flood control structure on the River Thames at Woolwich Reach in East London. It is 520 meters wide and protects London against storm surges and rainfall swelling.

Without the barrier the Houses of Parliament, the $\mathrm{O}^{2}$ arena, Tower Bridge and areas of Southwark, Beckton, West Ham, and Whitechapel would all be submerged in flood water.

It took eight years to build the structure, costing $£ 535 \mathrm{~m}$ ( $£ 1.6$ billion in today's money) and became fully operational in 1982.

The Thames Barrier is the second largest flood defence barrier in the world after the Oosterscheldekering Barrier in the Netherlands.

\subsubsection{Operation of Thames Barrier}

The barrier is a series of 10 separate movable steel gates, standing 20 meters tall and stretching 520 meters across the river.

Each of the main gates is a hollow steel-platted structure over $20 \mathrm{~m}$ high and weighing around 3,700 tonnes, capable of 


\section{International Journal of Science and Research (IJSR) \\ ISSN (Online): 2319-7064 \\ Index Copernicus Value (2013): 6.14 | Impact Factor (2014): 5.611}

withstanding an overall load of more than 9,000 tonnes of water.

When the barrier is closed, a solid steel wall sealing the upper part of the river from the sea is created, stopping water from flowing upstream towards the capital. The gates can also be part closed in the under spill position, allowing a controlled amount of water to pass under the gate and up the river.

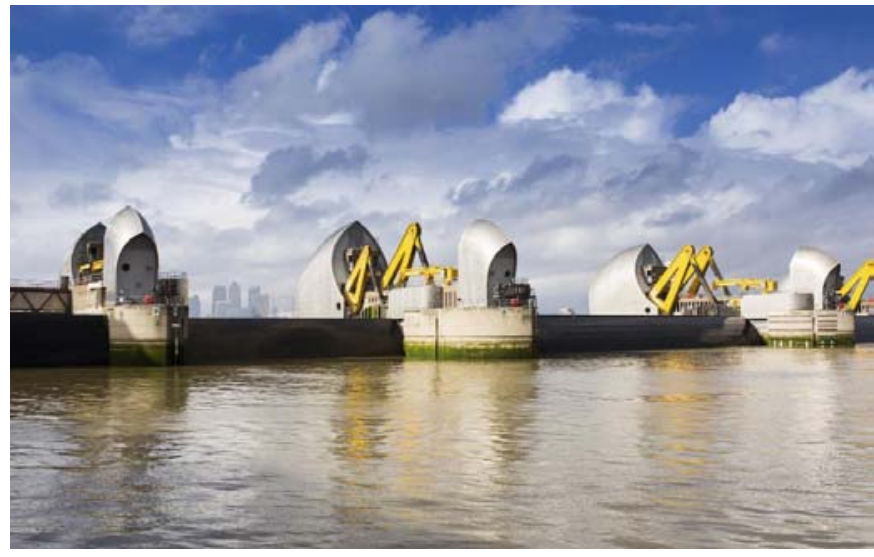

Figure 6: Thames Barrier

(Source: Wiki-media)
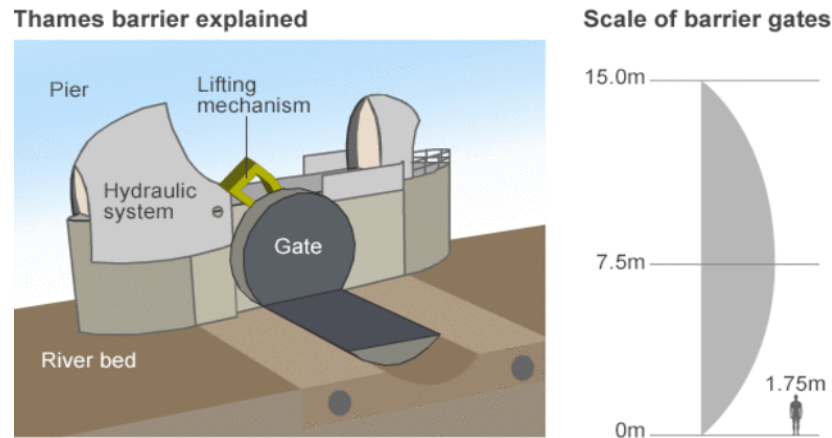

Figure 7A: Principle Components of Thames Barrier (Source: www.gov.uk/guidance/the-thames-barrier)

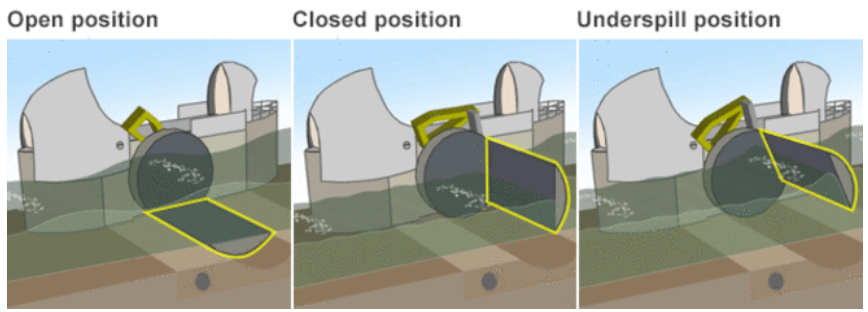

Figure 7B: Operating Principle of Thames Barrier ((Source: www.gov.uk/guidance/the-thames-barrier)

\subsection{Retarding Basin (Melbourne) from Australia}

Retarding basins play an important function in managing storm water in your local area. They are low lying areas of land set aside to temporarily store storm water during very high rainfall.

In Australia, they have managed over 200 retarding basins across Greater Melbourne with many recreational areas for the community.
They may be a grassy area available for recreation while dry, or hold water permanently which supports biodiversity.

When a retarding basin fills, the landscape is designed to hold back storm water to reduce flood risk to local homes and businesses. During this time, recreational areas may be affected. The stored water is then slowly released into the downstream drain or waterway.

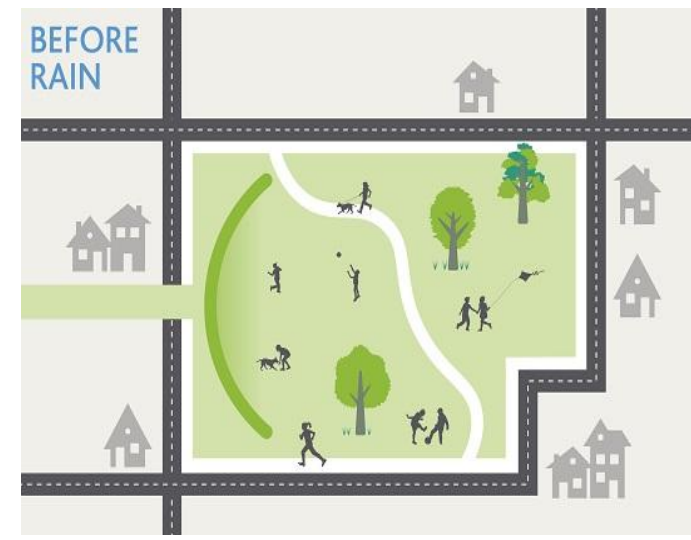

Figure 8: Schematic Explanation of Retarding Basins Before Rain

(Source: Melbourne Water)

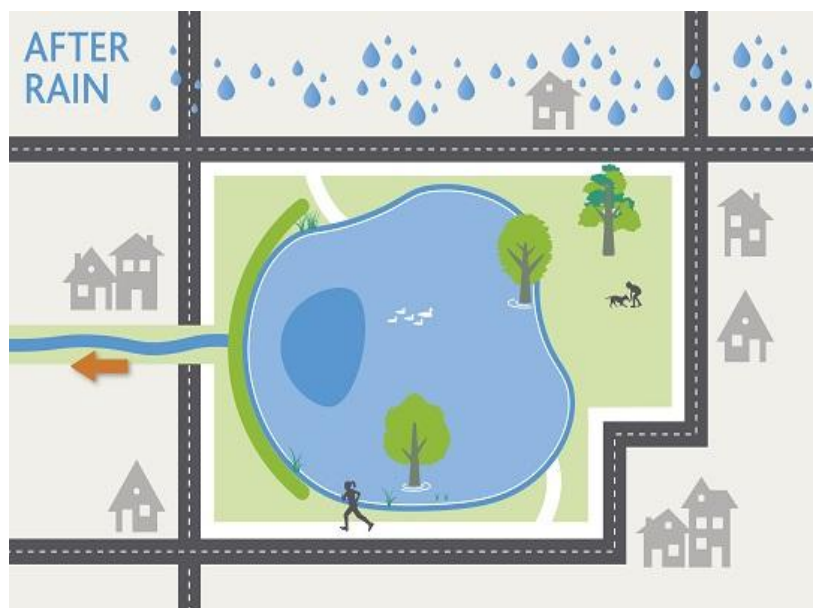

Figure 9: Schematic Explanation of Retarding Basins - After Rain

(Source: Melbourne Water)

\subsection{SMART Tunnel (Kuala Lumpur) from Malaysia}

Located at the confluence of the Klang and Gombak rivers, the area around Kuala Lumpur is prone to serious flooding. As the city continues to develop, growth has placed additional pressure on its drainage system's ability to cope with flash floods. Between 2000 and 2003, the city experienced devastating floodwater damage.

In 2004, the SMART (Storm water Management and Road Tunnel) project was initiated as a solution to control storm water. Kuala Lumpur would divert storm water before it entered the city center by constructing a 9.7-kilometer long tunnel, which could hold up to 1.0 million cubic-meters of water. The water could then be released into the river downstream from the city to prevent flooding. 


\section{International Journal of Science and Research (IJSR) \\ ISSN (Online): 2319-7064}

Index Copernicus Value (2013): 6.14 | Impact Factor (2014): 5.611

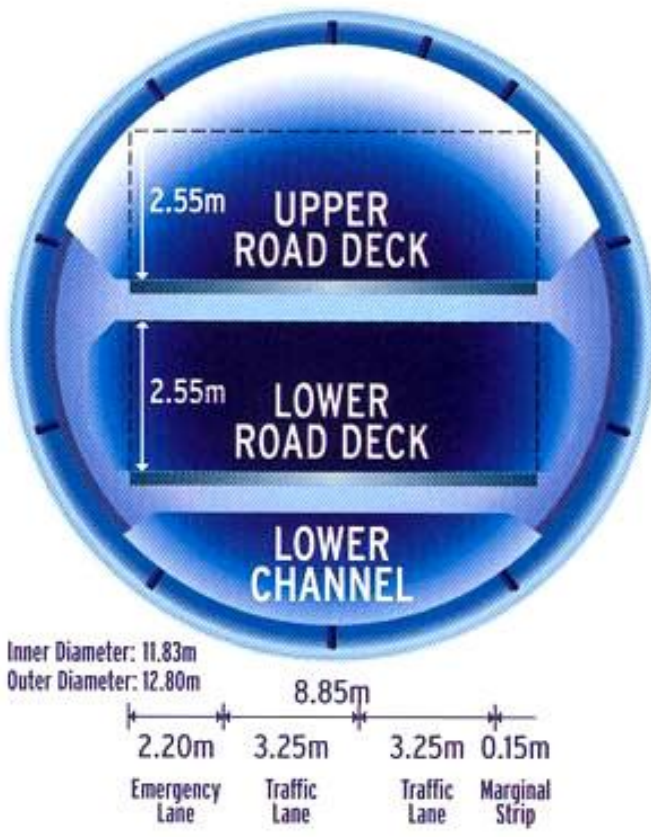

Figure 10: Motorway Tunnel Cross-Section (Source: Adapted from the Study and Evaluation on SMART Project, Malaysia in University of Southern Queensland)

\subsubsection{Principle Elements of SMART Tunnel:}

This US \$600-million project included several elements such as a holding basin with a floodwater storage capacity of 600,000 cubic meters, a reservoir with a capacity of 1.4 million cubic meters, a bypass tunnel $\&$ a control center for managing, operating and maintaining the SMART system

\subsubsection{Operation Modes of SMART Tunnel}

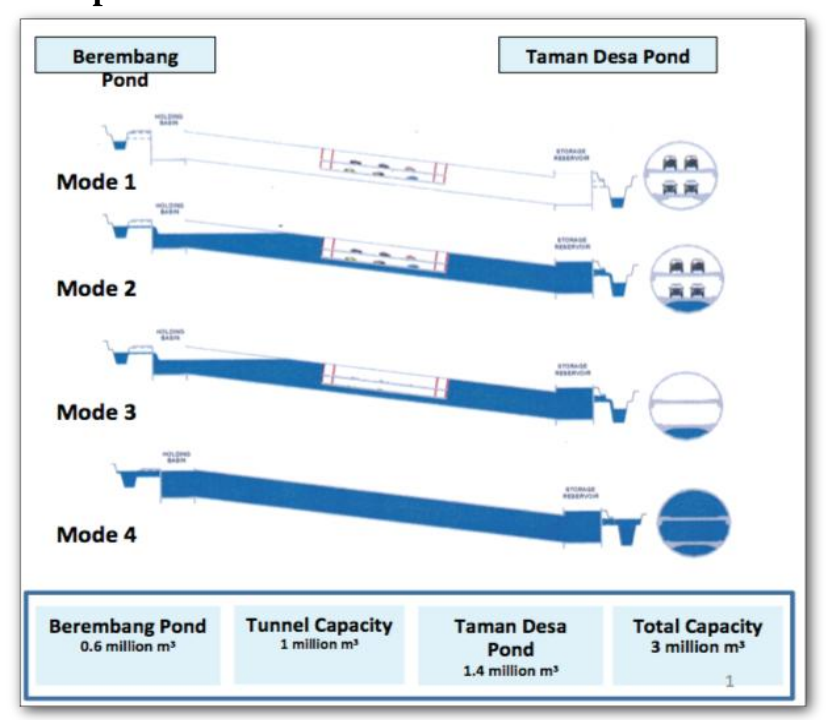

Figure 11: Operation Modes of SMART Tunnel (Source: SMART Management team, 2005)

$\boldsymbol{I}^{\text {st }}$ Mode: The first principle mode will be under normal condition. This is where, there are no flood situation arises in the city centre or low rainfall. In this case the overall upper deck and lower deck will be used fully has the traffic motorway. The computerized operation system will monitor the situation in order to run the tunnel smoothly $2^{\text {nd }}$ Mode: The Second mode is when there is flood water is diverted into the bypass tunnel by using the third deck (lower channel) .This happen when the rainfall is moderate and can be channeled thru only one deck. When this happen, the tunnel is still open foe vehicle to pass through as the bypass road. The two upper deck will be kept open include the lower channel section as the water is diverted.

$3^{\text {rd }}$ Mode: The third principle is when heavy storm hits the city. When this happens the system will close down the upper deck and lower deck to vehicle. The tunnel will be fully inspected before it is closed down to be fully used as a channel to diver the water. After these decks are closed the tunnel will be used only as storm water divert system. The flood water tight gates will open to allow the flood water to be channeled into the tunnel. The three decks will be used to channel the excess water from the city to a holding pond. After the storm is over the tunnel will be cleaned from rainwater sludge before vehicle is permitted to enter.

\subsection{The MAOUDC (Tokyo) from Japan}

The Metropolitan Area Outer Underground Discharge Channel, is an underground water infrastructure project in Kasukabe, Tokyo, Japan. It is the world's largest underground flood water diversion facility, built to mitigate overflowing of the city's major waterways during heavy rain.

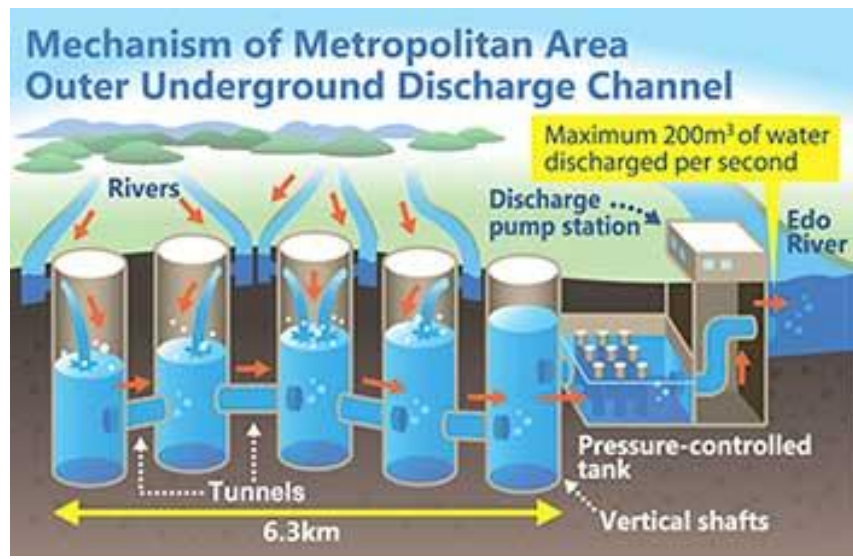

Figure 12: A schematic of the MAOUDC that drains flood water below ground, stores it and eventually discharges it into rivers

(Source: Web Japan, 2012)

\subsubsection{Construction Technology}

The cylindrical shafts are about $70 \mathrm{~m}$ tall. The large shafts measure about $30 \mathrm{~m}$ in diameter, spacious enough to park a space shuttle.

The connecting tunnel $50 \mathrm{~m}$ below ground measures about $10 \mathrm{~m}$ in diameter. The tunnel stretches for $6.3 \mathrm{~km}$, including a sharp curved line with a minimum radius of 250 meters.

Before being discharged into rivers, the drained water is stored in a huge pressure-controlled tank. The tank is designed to perform multiple functions, including abating the force of running water and adjusting water pressures that could change sharply if a water pump breaks down. 


\section{International Journal of Science and Research (IJSR) \\ ISSN (Online): 2319-7064}

Index Copernicus Value (2013): 6.14 | Impact Factor (2014): 5.611

Measuring $177 \mathrm{~m}$ long and $78 \mathrm{~m}$ wide, and lying about $22 \mathrm{~m}$ below ground, the water tank is larger than a soccer pitch.

The ceiling of the water tank is supported by 59 pillars which are $18 \mathrm{~m}$ tall and weigh 500 tons each.

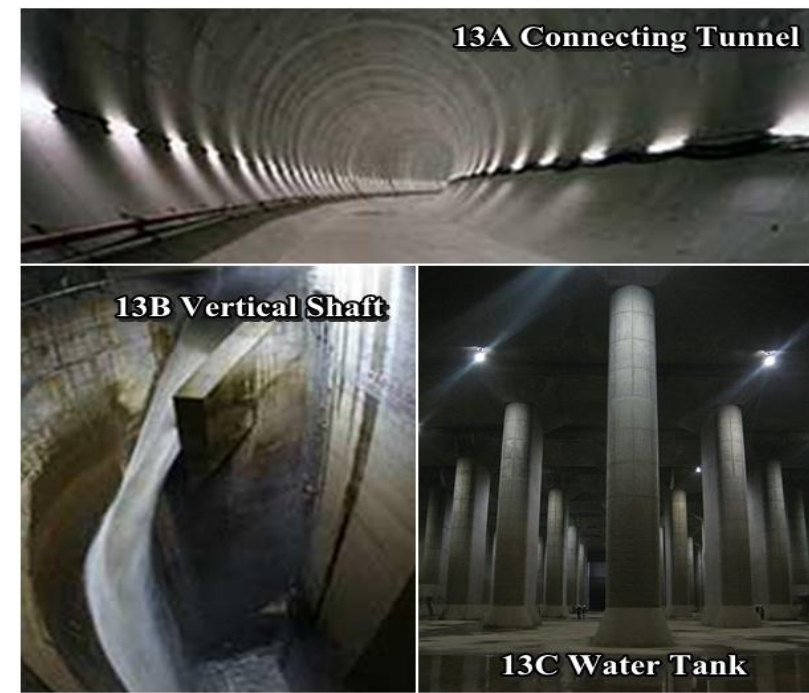

Figure 13: (A) Connecting Tunnel, (B) Vertical Shaft, (C) Water Tank of MAOUDC (Source: Web Japan, 2012)

\section{Conclusion}

In current time, in Ponneri, a town in a rural part of Chennai Metropolitan Area, developers are executing Chennai Metropolitan Development Authority-approved plans with no regard to drainage. During the heavy rains, Ponneri received $370 \mathrm{~mm}$ of rain $-135 \mathrm{~mm}$ more than Chennai did. While it suffered from flooding, damage to property and life was not high. Ponneri is slotted to be developed as a Smart City. But will our dumb engineers be able to build a smart city?

It can be simply concluded that natural disasters can be smoothly handled with growing civil engineering technologies with the giant examples from around the world. If a metropolitan city like Chennai needs to overcome the losses caused by heavy floods, it has to act rapidly towards sustainable urban development with the latest possible guidelines from the developed countries.

\section{References}

[1] Ar.K.Lavanya, Urban Flood Management - A Case Study of Chennai City", Architecture Research 2012, 2(6): 115-121.

[2] CMDA (2007), Master Plan - II for Chennai Metropolitan Area - 2026, March 2007, Chennai Metropolitan Development Authority, Tamil Nadu.

[3] CPREEC (2008), Urban Flood Studies for Chennai under NIDM Project, CPR Environmental Education Centre, Chennai.

[4] Calder, I. R. and Ailward, B. (2010), Forest and floods: moving to an evidence based approach to watershed and integrated flood management" Water Int., 31(1), 1-13

[5] Gupta, A. K. and Nair (2010), S. S., Flood risk and context of land uses: Chennai city case". J. Geogr. Reg. Plann., 3(12), 365-372.

[6] S.Surya, B.V.Mudgal, Assessment of Flood Potential Ranking of Sub watersheds: Adyar Watershed a case study", International Journal of Innovative Research in Science, Engineering and Technology. Vol.3, Issue 7, July 2014.

[7] Zameer Ahmed, D. Ram Mohan Rao, Dr.K.Ram Mohan Reddy, \& Dr. Y. Ellam Raj, Urban Flooding - Case Study of Hyderabad", Global Journal of Engineering, Design \& Technology. Vol 2(4):63-66

[8] M. Ghahroudi Tali \& M. A. Nezammahalleh, Urban flooding management using the natural drainage system case study: Tehran, capital of Iran", Floods: From Risk to Opportunity (IAHS Publ. 357, 2013), 174-180.

[9] Joseph Thomas, Sustainable Fresh Water Supply for Chennai city, Tamil Nadu, India A Status Update"

[10]Ir. Chia Chong Wing, Managing Flood Problems in Malaysia", Buletin Ingenneiur.

[11] Carlos E.M Tucci, Urban Flood Management”, World Meteorological Organization.

[12] A Report on Flood Risk Assessment", Melbourne Water.

[13] Spiire Australia, Wyndham North Storm water Management Stategy", May 2013.

[14]A Report on Guidelines for Development in FloodProne Areas", Melbourne Water.

[15] A dissertation submitted by, Ram kumar M.Kannapiran, -AStudy and Evaluation on SMART Project, Malaysia", University of Southern Queensland, October 2005.

\section{Author Profile}

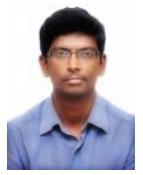

Saravanan J, have completed M.E Environmental Engineering and working as Assistant Professor in Department of Civil Engineering in Renganayagi Varatharaj College of Engineering, Sivakasi, TamilNadu, India.

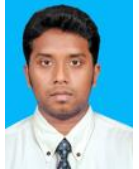

Naveen Chander K, have completed M.E Environmental Engineering and working as BIM Modeler in SYConE CPMC Pvt. Ltd. Bangalore, India 